How to cite this article:

Kuah, Y. C., Zakaria, Z., \& Choong, C. K. (2020). The impact of manager characteristic on capital structure in Malaysian manufacturing SMEs. International Journal of Banking and Finance, 15(1), 21-37. https://doi.org/10.32890/ijbf2020.15.1.9930

\title{
The Impact of Managerial Characteristics on Capital Structure in Malaysian Manufacturing SMEs
}

\author{
${ }^{1}$ Kuah Yoke Chin \\ ${ }^{2}$ Zuriawati Zakaria \\ ${ }^{3}$ Choong Chee Keong \\ Faculty of Business and Finance, \\ Universiti Tunku Abdul Rahman, Malaysia \\ ${ }^{1}$ Corresponding author: kuahyc@utar.edu.my; \\ 2zuriawatiz@utar.edu.my; \\ 33choongck@utar.edu.my
}

\section{A R T I C L E I N F O}

Article history:

Received 19 August 2019

Revised 14 November 2019

Accepted 26 November 2019

Published 31 March 2020

Keywords:

Managerial characteristics, manufacturing, SME, financing.

JEL Code: D24

\section{A B S T R A C T}

Access to capital is a critical factor in stimulating small business creation and growth especially in developing companies. The failure of small business entities in securing the needed capital would entail them remaining small and limit their ability to create goods, services, and innovations in the marketplace, including jobs. This study focuses on manufacturing SMEs by examining the influence of managerial characteristics (age, gender, work experience and level of education) on capital structure towards technology improvement. Based on a survey of 219 respondents, the results indicated that male managers, managers with a lot of work experience and educated managers preferred internal and external financing. Furthermore, internal and external financing also showed positive relationships to improve manufacturing technology 
performance. This study provides and adds new knowledge to corporate managers to serve as benchmarks in making decisions on company performance. It could also enhance company ability to deal with competitive environments.

\section{Introduction}

Business discontinuation is a crucial aspect of economic dynamics, and entries and exits of businesses are closely connected. Given that a large number of SMEs have been unsuccessful, it is expedient to investigate the causes of poor performance and failure of these firms (Arasti, 2011). The reasons for business failure are many and varied, such as limited sources of financing, low productivity and lack of business experience. The majority of studies on business failures focused on the business itself rather than on the owner of the business. It cannot be denied that entrepreneurs and related factors are critical factors that contribute to the failure of SMEs (Arasti, Zandi, \& Talebi, 2012).

According to Baldwin, Bian, Dupuy and Gellatly (2000), managerial experience and financial management were vital issues that determined the success or failure of a firm. Based on survey results, almost half of the Canadian insolvent firms became bankrupt due to internal problems caused by managerial inexperience and lack of knowledge in sustaining the business. Based on the findings in Arasti et al. (2012), the failed business owners and managers were mostly in the middle-aged group and they usually did not succeed in the establishment phase of the business. Their businesses did not survive more than three years because of their personal characteristics.

Management characteristics have contributed largely towards bankruptcy (Ooghe \& De Prijcker, 2008). Insufficient and inappropriate skills of management account for the failure of unsuccessful start-up companies. Additionally, some managers have experience in management but are without industry-related knowledge and display very authoritarian behaviour that increases the rigidity of the company. Apart from management qualities and skills, many personal characteristics strongly affect the performance of a company.

An increasing number of scholars (Zabri, 2012; Borgia \& Newman, 2012) have begun to question the role played by owners' or managers' characteristics and attitude as critical factors in SMEs. Owners or managers have substantial influence on financing decisions in a company (Borgia \& Newman, 2012). 
Companies in the same industry have management whose characteristics differ. They employ different capital structure models resulting in diverse outcomes (Kyenze, 2014). Many researches have discussed the relationship between managers' characteristics and debt financing, but little has been done in the Malaysian context, especially in SMEs. Thus, this study attempts to bridge the gap, given that an analysis of managers' characteristics is crucial to understanding the capital structure of firms.

The purpose of this study is to examine if there is any significant managerial characteristic(s) such as age, gender, level of education or background experience which influences the composition of a firm's capital structure. Next, this study will investigate the effect of internal and external financing on technology improvement.

\section{Theoretical Model}

The theories suggest that firms decide on a capital structure based on attributes that determine the various costs and benefits associated with debt and equity financing (Abor \& Biekpe, 2009). After the work of Modigliani and Miller (1958), several theories of capital structure have been developed to explain the optimal capital structure. Pecking order theory, trade-off theory and agency theory are among the most popular theories on capital structure.

The Modigliani and Miller Theory (M\&M) forms the foundation of capital structure theories (Kumar \& Rao, 2015). The assumption of the Modigliani and Miller Theory (1958) is that firms have a particular set of expected cash flows. After selection of a certain proportion of debt and equity to finance a firm's assets, the cash flow would be allotted among its investors. Investors and firms are assumed to have equal access to financial markets, which allows for homemade leverage. Therefore, the leverage of a firm has no effect on the market value of the firm (Luigi \& Sorin, 2009). M\&M assumes that the market is perfect and has no influence on the value of a firm; investors have homogeneous expectations; it is a tax free economy and there are no transaction costs. However, this theory is inapplicable as it is based on restrictive assumptions and is inconsistent with the real world. Investors prefer to buy undervalued shares and sell at higher prices to earn income (Salim \& Yadav, 2012). Hence, Modigliani and Miller (1963) revised their position by incorporating tax benefits as determinants of capital structure. To strengthen this argument, M\&M explained that a firm that honors its tax obligations benefits from partially offsetting interest called tax shield in the form of payment of lower taxes. Thus, firms are able to maximize their value by employing debt due to tax shield benefits associated with debt use (Ahmad, Abdullah \& Roslan, 2012). M\&M was criticized due to some weaknesses and 
inapplicable assumptions. Nevertheless, it provided the foundation for other theories put forth that took into consideration market imperfections. The M\&M has been expanded into the pecking order theory and trade-off theory.

The pecking order theory (POT) propounded by Myers and Majluf (1984) argues that firms prioritize their sources of financing and that they usually prefer internal financing. If external financing is needed then debt is chosen and equity would be the last resort. To avoid the underinvestment problem, managers seek to finance new projects using a security that is not undervalued by the market, such as internal funds and riskless debt. This is because a firm has more information than outsiders and information asymmetry investors demand more premiums for information-sensitive securities (e.g. equity). This implies that firms with high levels of profit have a lower leverage ratio as they are capable of financing investment needs through internal sources, and therefore external sources are not necessary. However, when the company is unprofitable, they tend to use debt as external financing when their cash flow is not enough to fulfill investment needs (Dwaikat et al., 2014).

The second theory is trade-off theory (TOT) which implies that leverage has a positive relationship which is contrary to the pecking order theory. It assumes the presence of an optimal capital structure that maximizes shareholder's wealth and simultaneously minimizes external claims to wealth. It considers the trade-off between benefits of interest tax shield of debt and cost of financial distress (Kumar \& Rao, 2015). The advantage of borrowing allows companies to attain tax shield, that is, a company pays lower tax when it incurs more debt. Companies are most likely to use debt financing up to a certain level until the cost of financial distress starts to surface (Saarani \& Shahadan, 2013). A highly leveraged firm with a high debt ratio is always associated with the need for high returns. This is because the firm is exposed to bankruptcy risks if not managed well. This explains why highly leveraged firms require high returns to compensate for the risk. Incidentally, interest payment for debt is tax-deductible. An optimal capital structure could therefore be achieved by the firm to enjoy maximum tax benefits. To conclude, trade-off theory gathers the pros and cons of the usage of debt. The usage of debt in capital structure gives a reduction in tax burden; however, an increase in the level of debt comes with the risk of bankruptcy, since the likelihood of bankruptcy rises with the degree of the company's indebtedness (Dwaikat et al., 2014).

The last theory is agency cost provided by Jensen and Meckling (1976) which discusses the conflict of interest between principals (shareholders) and decision makers (agents) of firms (managers, board members, etc.). This conflict stems from the differences in behaviour or decisions by pointing out that the parties (agents and shareholders) often have different goals, and different tolerances towards risk. For instance, some managers tend to guide the firm 
towards achieving their personal goals rather than maximizing benefits for the shareholders. Hence, the main conflict that shareholders face is ensuring that managers (agents) do not invest free cash flow in unprofitable projects (Nassar, 2016). In companies with high cash flow and profitability, increase in debts can be used as a toll for reducing the scope of the manager in order that resources of the company may not be wasted as a result of their activities (Negasa, 2016). There are some researchers who argue that leverage ratio is high when managerial ownership is low, as agency cost is also low.

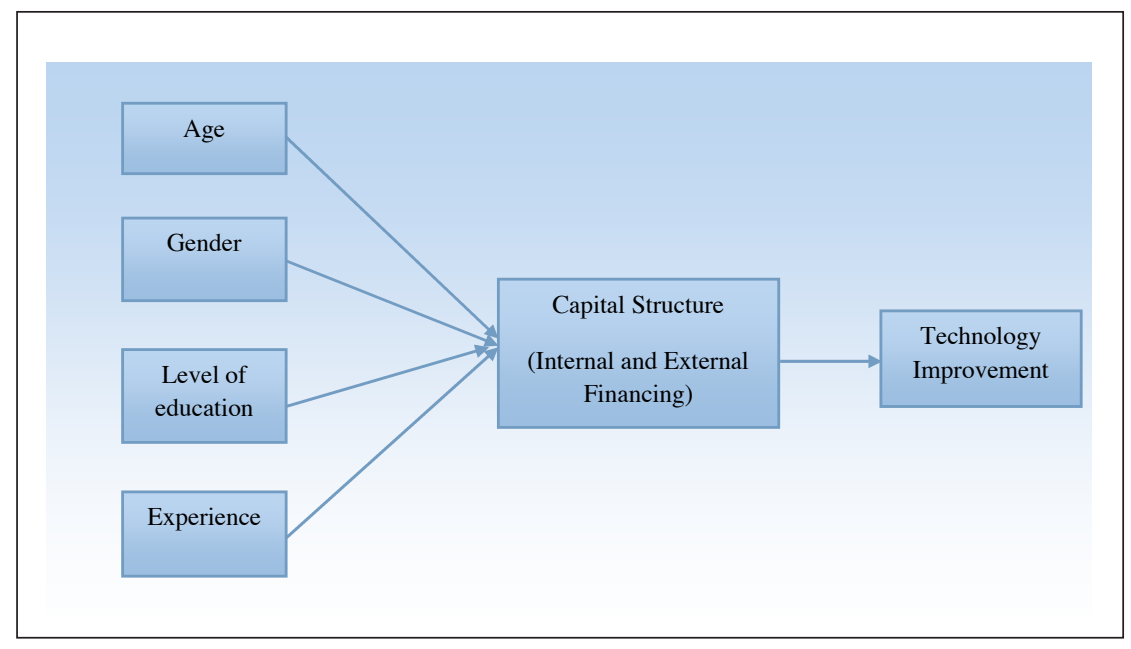

Figure 1. Theoretical Model (Sources: Developed for research)

\section{Manager's Characteristics and Financing Preferences}

The subject of capital structure has been extensively examined. Despite the enormous amount of literature that analyzed the capital structure of companies, studies conducted on this subject related to managerial characteristics are limited (Dwaikat et al., 2014). Most of the theoretical and empirical studies that addressed these topics concentrated on the large number of listed firms that dispersed ownership structure. It is doubtful that these findings could be applied to firms under the control of large stockholders, especially those owned by families; in particular, small and medium enterprises (SMEs) which have specific goals to concentrate on their survival in the long run. It is argued that SMEs have more aversion to risk than listed companies. To prevent the entrance of new stockholders, small companies will employ debt in the capital as leverage. 


\subsection{Age}

CEOs need to be of a mature age as they are tasked with making important decisions, especially related to external financing (Kyenze, 2014). Aterido, Beck and Lacovone (2011) reported that older individuals are more likely to use formal banking services compared to younger people. However, the findings of Uddin (2014) and Zabri and Lean (2014) revealed that the problem faced in raising debt capital does not differ with the age of entrepreneurs. This is contradictory as earlier research by Coleman and Carsky, (1999) suggested that young entrepreneurs were noted to be more likely to use external credit. Based on data taken from the 1993 National Survey of Small Business Finances, the authors found that a young entrepreneur sees growth potential in his firm as compared to a mature manager and thus requires more external capital to fund its growth. Older managers tend to be more risk averse whereas younger managers are willing to undertake risky innovative growth strategies (Ting, Azizan, \& Kweh, 2014). From the survey in the US and UK on SME financing, Vos, Yeh, Carter and Tagg (2007) reported that young entrepreneurs of SMEs utilized external financing more actively while older entrepreneurs relied on a great extent on retained profits. Bogdana (2009) attempted to summarize and compare the findings on the impact of the age of CEOs on capital structure. He concluded that a CEO's age is negatively, statistically and significantly related to corporate capital structure, based on fixed and random effects in panel data. This means that the older the CEOs, the more conservative they become, and consequently, the less they borrow.

$H_{1}$ : There is a positive relationship between managers'age and leverage in Malaysian manufacturing SMEs.

\subsection{Gender}

There is less evidence of actual discrimination by financial institutions against female SME owners in terms of the average time taken to approve a loan, the tenure (term) of the loan or the interest rate charged (Watson, Newby \& Mahuka, 2009). The findings failed to uncover any perceptions of discrimination by financial institutions against female SME owners. Therefore, there is no difference in bank loan rejection rates by gender. The problem faced in raising debt capital does not vary with the gender of entrepreneurs (Cassar, 2004; Uddin, 2014; Zabri \& Lean, 2014; Kyenze, 2014) However, Fourati and Affes (2013) found that men are more likely to obtain external funding than women. Male business owners make the most use of external sources of finance, notably bank overdrafts, bank loans and suppliers' credit (Vos et al., 2007). 
Interestingly, Constantinidis, Cornet and Asandei (2006) found that women entrepreneurs in the industry sector resorted to bank loans to expand the operational size of their firms. Irwin (2007) pointed out that men are more likely to use family and friends' advice to access finance for SMEs in the UK, whilst women seek external advice, such as from business links and enterprise agencies. In 2007, a majority of female-owned firms sought external funding just as the majority of male-owned firms (Jung, 2010). Yet, female managers are more risk-averse and borrow less on behalf of the company (Bogdana, 2009). The decision on the amount of borrowings is not dependent on the gender of the CEO, as it is collectively made during executive board meetings. Women experienced more problems in raising external funds than their male counterparts (Wellalage, Dupati, \& Fauzi, 2013; Kapunda, 2016). The female entrepreneurs in the African countries have to overcome greater legal barriers compared to their male peers (Aterido et al., 2011). Firms with female CFOs face tighter credit availability and are more often required to provide collateral despite their approved loans. Furthermore, banks prefer to claim mortgage collaterals when lending to companies under the control of female CFOs, while they are more inclined to require guarantee collaterals when lending to companies under the control of male CFOs. This suggests that the collateral clauses are more restrictive to female than to male CFOs. Thus, it could be surmised that female CFOs are less likely to obtain external financing from financial institutions (Xu, Li, \& Chang, 2016).

\section{H2: $\quad$ Male managers are preferred in debt financing than female managers.}

\subsection{Education}

Highly educated entrepreneurs are able to manage their businesses better than those who are less educated. In addition, education is a strong predicator of the use of banking services, with linear increase in its use in most countries (Aterido et al., 2011). Highly educated entrepreneurs are usually successful in managing SMEs (Chong \& Mahmoud, 2013) and CEOs who have MBAs or law degrees tend to have greater leverage (Frank \& Goyal, 2007), and therefore resort to banks and external financing (Fourati \& Affes, 2013). This could be attributed to the fact that they have sufficient financial knowledge and are aware of the varied sources of financing. A manager's level of education is significantly related to debt financing (Zabri \& Lean, 2014) and firm performance (Kyenze, 2014). Constantinidis et al. (2006) studied financing patterns of enterprises owned by women in Belgium and found that women owners with low educational levels were more likely to encounter problems with regard to access to financing 
than those who were highly educated. Indeed, women with higher educational qualifications and additional training are in an advantageous position in terms of securing financing. The less educated SME owners tend to actively seek external financing to avert the fear of loan denials (Vos et al., 2007). However, Zabri, Ahmad and Lean (2015) noted that the more knowledgeable the ownermanagers, the lesser their preference for external equity financing. Whereas, Borgia and Newman (2012) showed that the education level of owners or managers in Chinese SMEs did not significantly impact the amount of debt used in their capital structure. This was consistent with earlier findings by Cassar (2004) who affirmed that educational levels of entrepreneurs did not impact financing preferences.

$H_{3}$ : There is a positive relationship between managers' education and leverage in Malaysian manufacturing SMEs.

\subsection{Experience}

A manager's experience could be considered as a measure of reputation and private entrepreneurs who are experienced are more likely to choose formal financing. Managers with a greater level of business experience are found to take advantage of bank financing (Zabri et al., 2015). This is because owner's or manager's experience plays an important role in reducing asymmetric information flow between the firm and external investors. Borgia and Newman (2012) observed that the owner's or manager's experience is significantly and positively related to the level of a firm's leverage. Fourati and Affes (2013) stated that high industrial experience increases the probability of using external equity in financing venture activities. Hence, high capital requirements for large firms discourage inexperienced and undercapitalized entrepreneurs from undertaking large ventures (Parsa, Rest, Smith, Parsa and Bujisic, 2015). Constantinidis et al. (2006) noted that women did not encounter problems of access to external financing if they had business experience, that is, they had worked as employees or were owners in the family business. However, according to Cassar (2004), Bogdana (2009), Zabri and Lean (2014), and Klacmer Calopa et al. (2014), the diverse experiences of entrepreneurs did not appear to impact on financing preferences. On the contrary, Scott and Irwin (2009) found that inexperienced owner-managers faced difficulties raising debt. They did not have enough credit scoring to obtain loans compared to the more experienced entrepreneurs.

$H_{4}$ : There is a positive relationship between managers' experience and leverage in Malaysian manufacturing SMEs. 


\section{Methodology}

The data was collected using structured questionnaire survey. Prior to using the questionnaire for data collection, a detailed pre-pilot test was conducted by sending the questionnaires to 30 Malaysian manufacturing SMEs to increase its validity. The pilot study helped to dispel doubts about the validity and reliability of the instrument. Thus, the final questionnaire incorporated suggestions obtained from the pilot study and necessary amendments were made. The developed questionnaire consisted of two sections. Section one captured the demographics of the respondents (managers or owners) such as age, gender, level of education and experience. Section two, required the respondents to indicate their preferences on capital structure, sources of funding and their technology performance. Census method is the best method to collect data from SMEs listed in the SME Corp. as it incorporates all companies in the manufacturing sector from the FMM directory 2018. Out of the 1365 questionnaires distributed, 235 sample responses were returned. However, only a total of 225 of the questionnaires were usable. 10 questionnaires were not included in the data analysis due to incomplete response. A total of 225 respondents represented approximately 15.6 percent covering a broad range in the Malaysian manufacturing sector. This response rate of 15.6 percent is a common response rate within the context of research in Malaysian manufacturing companies (Olusegun, Hasbullah, \& Nordin, 2014). However, there were six sets of questionnaires which fell out of the range and were considered as outliers. Henceforth, the data set in this study was 219 after removing the undesirable outliers.

\section{Results}

\subsection{Descriptive Analysis}

This study employed a sample size of 219 respondents with the following descriptive characteristics: 45.2 percent were male and 54.8 percent were female. Most of them were Chinese from the age of 31 to 40 years old. 81 percent of the respondents had more than 5 years to 10 years of work experience. The majority of the respondents were owners/managers who had work experience in local private firms. 
Table 1. Demographic Profile of Respondents

\begin{tabular}{lcc}
\hline & Frequency & Percentage (\%) \\
\hline Gender & & \\
Male & 99 & 45.2 \\
Female & 120 & 54.8
\end{tabular}

Age

Below 20

$0 \quad 0$

21-30

$49 \quad 22.4$

$31-40$

92

42.0

41-50

63

28.8

51 and above

15

6.8

Ethnicity

Malay

4

1.8

Chinese

211

96.3

Indian

4

1.8

Level of education

No formal education

$\begin{array}{cc}0 & 0 \\ 7 & 3.2 \\ 0 & 0 \\ 18 & 8.2 \\ 121 & 55.3 \\ 121 & 55.3 \\ 10 & 4.6 \\ 0 & 0 \\ 0 & 0 \\ 2 & 0.9\end{array}$

Current position

Owner

Owner/Manager

70

32.0

Finance Manager

71

32.4

Accounting Manager

31

14.2 
Frequency

Percentage $(\%)$

Length of service

Less than 3 years 55

More than 3 years to 5 years

23

10.5

More than 5 years to 10 years

141

64.4

More than 10 years

0.0

Work Experience

Yes

No

Work Experience As

Owner

Shareholder

Employee

Others

Work Experience in

Local private firm

Government service

Multinational corporation (MNC)

Government linked company (GLC) 36

Others

Sources: Developed for research

\subsection{Findings and Discussion}

All collected data were analyzed using Statistical Package for the Social Sciences (SPSS) version 23 and Partial Least Squares-Structural Equation Model (PLS-SEM). The structural model was analyzed using SmartPLS 3.2 to perform PLS-SEM to test the hypothesized relationships between independent variables (such as age, gender, level of education and experience of respondents) with dependent variable as leverage in Malaysian manufacturing companies as shown in Figure 2. 


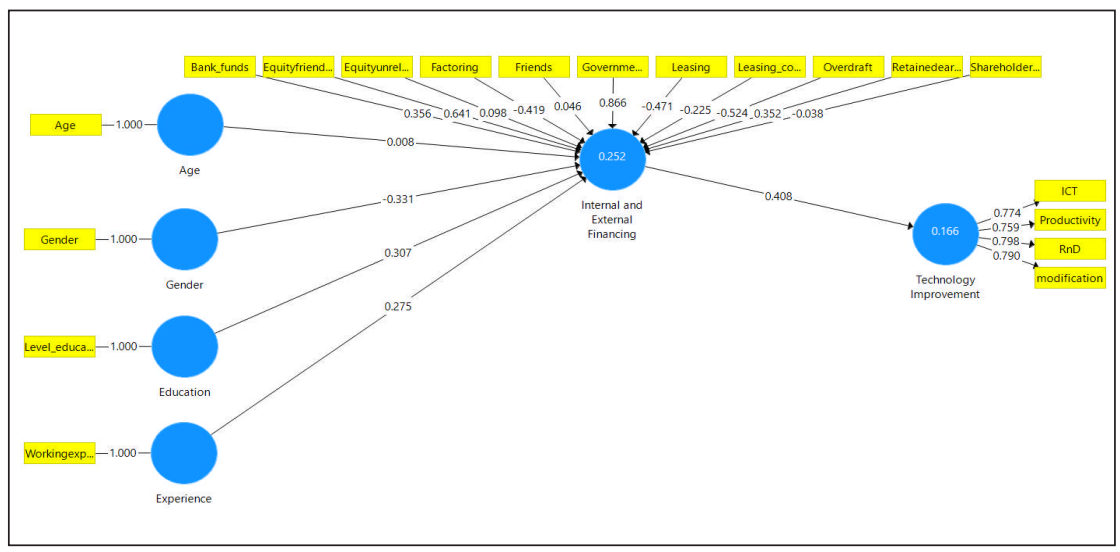

Figure 2. Diagram of Second-order Constructs.

There are several steps for formative measurement. The first step is to conduct a collinearity assessment of indicators. Collinearity is assessed by computing the tolerance which represents the amount of variance of one formative indicator that is not explained by other indicators in the same block. Variance inflation factor (VIF) is a reciprocal of the tolerance and it is a related measure of collinearity. A VIF value of 5 or higher shows the potential presence of a collinearity problem in PLS-SEM (Hair, Ringle, \& Sarstedt, 2011). Table 2 shows that all the VIFs of the indicators are below the threshold of 5, suggesting that these indicators are distinct and that there is no collinearity problem. The next step in accessing the formative measurement model is by assessing the significance and relevance of the formative indicators if there is no collinearity issue in the formative measurement. This procedure is carried out by undergoing the bootstrapping procedure. Table 2 summarizes the results for the formative measure of internal and external financing by showing the original outer weight estimates, t-values, and significance levels.

The findings from Table 2 shows that gender significantly influenced decisions to obtain internal and external funding at 5\% level of significance. Gender showed a negative association with external funding decision. It suggested that male CEOs in the manufacturing sector had less reliance on the use of external financing for company growth. As compared to women entrepreneurs in the industrial sector who relied more on bank loans as a source of financing to expand business operations (Constantinidis et al., 2006; Irwin, 2007; Jung, 2010). The age of CEOs showed a positive but insignificant relationship with company decision to use or not to use external financing. 
Table 2. Formative Measure, Variance Inflation Factor (VIF) and Outer Weight Significance Test Results

\begin{tabular}{llcccc}
\hline $\begin{array}{l}\text { Dependent } \\
\text { Variable }\end{array}$ & $\begin{array}{l}\text { Independent } \\
\text { Variable }\end{array}$ & VIF & $\begin{array}{c}\text { Outer } \\
\text { Weights }\end{array}$ & T Statistics & Significance \\
\hline $\begin{array}{l}\text { Internal } \\
\text { and }\end{array}$ & Age & 1.000 & 1.000 & 0.044 & No \\
$\begin{array}{l}\text { External } \\
\text { Financing }\end{array}$ & Gender & 1.000 & 1.000 & $1.565^{* *}$ & Yes \\
& $\begin{array}{l}\text { Level of } \\
\text { Education }\end{array}$ & 1.000 & 1.000 & $1.596^{* *}$ & Yes \\
& $\begin{array}{l}\text { Work } \\
\text { Experience }\end{array}$ & 1.000 & 1.000 & $1.528^{*}$ & Yes \\
\hline
\end{tabular}

Note: $* * *$ Significant at 1 percent, ${ }^{* *}$ significant at 5 percent, ${ }^{*}$ significant at 10 percent

Nevertheless, problems faced by companies in raising debt financing were equally the same regardless of whether the manager was younger or older (Zabri \& Lean, 2014). Ting, Azizan and Kweh (2014) reported that younger managers preferred to take risks to increase company growth and relied on external financing compared to older managers. Work experience showed a positive relationship with company source of capital at $10 \%$ significant level. Experienced managers in the manufacturing sector focused more on internal or external financing to increase their company performance. With their vast experience, these managers know the consequences they may need to face when using external financing. Therefore these managers are more cautious when choosing debt capital. This result concurred with previous studies by Borgia and Newman (2012), Fourati and Affes (2013) and Zabri et al. (2015) who found that managers with high levels of business experience chose bank financing to reduce asymmetric information between company and investors. The more highly educated the managers, the higher the probability of them choosing external financing. The results showed a strong positive relationship between the level of education and source financing at 5\% significant level. Furthermore, internal and external financing also shows a positive relationship at $1 \%$ significant level in improving manufacturing technology performance in Table 3. 
Table 3. Relationship of Internal and External Financing on Technology Improvement

\begin{tabular}{lll}
\hline Dependent Variable & T Statistics & Independent Variable \\
\hline Technology Improvement & $2.338 * * *$ & Internal and External Financing \\
\hline Note: ${ }^{* *}$ significant at 1 percent, & $* *$ significant at 5 percent, ${ }^{*}$ significant at 10 percent
\end{tabular}

\section{Conclusion}

A total of 219 responses were collected from a survey to examine the impact of managerial characteristics namely age, gender, work experience and level of education on source of capital financing of SMEs (in the manufacturing sector). Based on PLS SEM bootstrapping, the results revealed that only managers' age showed an insignificant influence on company leverage decision. The level of education and work experience strongly influenced managers when making decisions to use internal or external financing. Managers who were more educated with work experience preferred to use external financing. The findings were in line with the trade-off theory where more knowledgeable managers know the benefits of lower tax payments when incurring debt, however, the bankruptcy clause is increased if they are unable to generate higher returns to compensate risks. Therefore, these managers may prefer to use internal financing to finance the growth of the company. Managers' gender also showed a negative and significant relationship to leverage. Thus, financial decisions by management are crucial in ensuring that a firm's capital structure is optimal. Different managements have different leverage privileges with managers trying to attain optimal capital structure. Variations in capital structure affect the costs of equity or debt and thereby, have an impact on the capital costs of firms. Therefore the choice of type of debt in the capital structure is important for all companies.

\section{References}

Ahmad, Z., Abdullah, N. M. H., \& Roslan, S. (2012). Capital structure effect in firm performance: Focusing on consumers and industrials sectors in Malaysian firms. International Review of Business Research papers, 8(5), $137-155$.

Arasti, Z. (2011). An empirical study on the causes of business failure in the Iranian context. African Journal of Business Management, 5(17), 74887498. 
Arasti, Z., Zandi, F., \& Talebi, K. (2012). Exploring the effect of individual factors on business failure in Iranian newly established small businesses. International Business Research, 5(4), 2.

Aterido, R., Beck, T., \& Lacovone, L. (2011). Gender and finance in Sub-Saharan Africa: Are women disadvantaged? World Bank Policy Research Working Paper Series.

Baldwin, J. R., Bian, L., Dupuy, R., \& Gellatly, G. (2000). Failure rates for new Canadian firms: New perspectives on entry and exit. Failure Rates for New Canadian Firms: New

Bogdana, D. (2009). Corporate capital structure choice: Does managers' gender matter. Working thesis, Kyiv School of Economics.

Borgia, D., \& Newman, A. (2012). The influence of managerial factors on the capital structure of small and medium-sized enterprises in emerging economies: Evidence from China. Journal of Chinese Entrepreneurship, 4(3), 180-205.

Cassar, G. (2004). The financing of business start-ups. Journal of Business Venturing, 19(2), 261-283.

Chong, K. G., \& Mahmoud, K. A. (2013). The determinants of SME succession in Malaysia, from entrepreneurship perspective. Journal of Advanced Social Research, 3(12), 350-361.

Constantinidis, C., Cornet, A., \& Asandei, S. (2006). Financing of womenowned ventures: The impact of gender and other owner-and firm-related variables. Venture Capital, 8(2), 133-157.

Coleman, S., \& Carsk, M. (1999). Sources of capital for small family-owned businesses: Evidence from the national survey of small business finances. Family Business Review, 12(1), 73-84.

Dwaikat, N. K., Queiri, A. R., \& Aziz, M. N. (2014). Capital Structure of Family Companies. International Conference on Business, Law and Corporate Social Responsibility (ICBLCSR'14).

Frank, M. Z., \& Goyal, V. K. (2007). Corporate leverage: How much do managers really matter? Available at SSRN 971082.

Fourati, H., \& Affes, H. (2013) The capital structure of business start-up: Is there a pecking order theory or a reversed pecking order? -Evidence from the panel study of entrepreneurial dynamics. Technology and Investment, 4(4), 244.

Hair, J. F., Ringle, C. M., \& Sarstedt, M. (2011). PLS-SEM: Indeed a silver bullet. Journal of Marketing Theory and Practice, 19(2), 139-151.

Irwin, D. (2007). How SME owner's characteristics influence external advice and access to finance. Aston University.

Jung, O. (2010). Small Business Financing Profiles: Women Entrepreneurs, SME Financing Data Initiative. 
Kapunda, S. M. (2016). SME Finance, development and trade in Botswana: A gender perspective. Business Management Review, 11(1). 30-54.

Klacmer Calopa, M., Horvat, J., \& Lalic, M. (2014). Analysis of financing sources for start-up companies. Management: Journal of Contemporary Management Issues, 19(2), 19-44.

Kyenze, A. M. (2014). The effect of managers' characteristics on the capital structure of firms listed at the Nairobi securities exchange. Doctoral dissertation, University of Nairobi.

Luigi, P., \& Sorin, V. (2009). A review of the capital structure theories. Annals of Faculty of Economics, 3(1), 315-320.

Ooghe, H., \& De Prijcker, S. (2008). Failure processes and causes of company bankruptcy: A typology. Management Decision, 46(2), 223-242.

Parsa, H. G., Rest, J. P. I, Van der, Smith, S. R, Parsam, R. A., \& Bujisic, M. (2015). Why restaurants fail? Part IV the relationship between restaurant failures and demographic factors. Cornell Hospitality Quarterly, 56(1), 80-90.

Saarani, A., \& Shahadan, F. (2013). The determinants of capital structure of SMEs in Malaysia: Evidence from enterprise 50 (E50) SMEs. Asian Social Sciences, 9(6), 64.

Salim, M., \& Yadac, R. (2012). Capital Structure and firm performance: Evidence from Malaysian listed companies. Proceedings-Social and Behavioral Sciences, 65, 156-166.

Scott, J. M., \& Irwin, D. (2009). Discouraged advisees? The influence of gender, ethnicity and education in the use of advice and finance by UK SMEs. Environment and Planning C: Government and Policy, 27(2), 230-245.

Ting, I. W. K., Azizan, N. A., \& Kweh, Q. L. (2014). Human governance and firm's leverage decision: Evidence from Malaysian listed companies. Social Sciences \& Humanities, 22(3), 879-890.

Uddin, M. A. (2014). Problems faced by micro, small and medium enterprises in raising debt capital. Proceedings of the Social Sciences ICSSR.

Vos, E., Yeh, A. J. Y., Carter, S., \& Tagg, S. (2007). The happy story of small business financing. Journal of Banking \& Finance, 31(9), 2648-2672.

Watson, J., Newby, R., \& Mahuka, A. (2009). Gender and the SME "finance gap". International Journal of Gender and Entrepreneurship, 1(1), 4256.

Wellalage, N., Dupati, G., \& Fauzi, F. (2013). Institutional factors create additional glass ceilings: Evidence from female owned South-Asian SMEs' access to external financing. Asian Institute of Management.

Xu, X., Li, Y., \& Chang, M. (2016). Female CFOs and loan contracting: Financial conservatism or gender discrimination? An empirical test based on collateral clauses. China Journal of Accounting Research, 9(2), 153173. 
Zabri, S. M. (2012). The determinants of capital structure among SMES in Malaysia. In Proceedings of International Conference of Technology Management, Business and Entrepreneurship.

Zabri, S. M., \& Lean, J. (2014). SME managers' financing preferences: The case of successful SMEs in Malaysia. In Proceedings of 5th Asia Pacific Business Research Conference.

Zabri, S. M, Ahmad, K., \& Lean, J. (2014). Understanding owner-managers' preferences towards different sources of financing: The case of successful SMEs in Malaysia. Advanced Sciences Letter, 21(5), 1435-1438. 